\section{Why we should not extend the 14-day rule}

\author{
Bruce Philip Blackshaw (ㄷ, ${ }^{1}$ Daniel Rodger (1) ${ }^{2}$
}

\begin{abstract}
The 14-day rule restricts the culturing of human embryos in vitro for the purposes of scientific research for no longer than 14 days. Since researchers recently developed the capability to exceed the 14-day limit, pressure to modify the rule has started to build. Sophia McCully argues that the limit should be extended to 28 days, listing numerous potential benefits of doing so. We contend that McCully has not engaged with the main reasons why the Warnock Committee set such a limit, and these still remain valid. As a result, her case for an extension of the 14-day rule is not persuasive.
\end{abstract}

\section{INTRODUCTION}

The 14-day rule restricts the culturing of human embryos in vitro for scientific research to a maximum of 14 days. Proposed by the UK's Warnock Committee in $1984,{ }^{1}$ it was implemented in the UK Human Fertilisation and Embryology Act 1990. ${ }^{2}$ The rule has been highly influential and adopted by many other countries.

In 1984, it was not possible to culture human embryos in vitro for 14 days. Recent scientific advances now mean it is feasible to culture embryos beyond this limit, ${ }^{3}$ and consequently, pressure is growing for the 14-day rule to be extended. ${ }^{4-6}$

Sophia McCully has recently argued that it should be extended to 28 days. ${ }^{4}$ In response, we argue that the Warnock Committee's reasons for proposing the 14-day rule are still applicable, despite advances in our ability to culture human embryos in vitro.

\section{THE WARNOCK COMMITTEE}

In 1982, in response to public concern regarding in vitro fertilisation, the UK government established a Committee of Inquiry into Human Fertilisation and Embryology. ${ }^{1}$ Known as the Warnock Committee, after its chair, Mary

\footnotetext{
'Department of Philosophy, University of Birmingham, Birmingham B15 2TT, UK

${ }^{2}$ Allied Health Sciences, London South Bank University School of Health and Social Care, London, UK
}

Correspondence to Bruce Philip Blackshaw, Philosophy, University of Birmingham, Birmingham, UK; bblackshaw@gmail.com
Warnock, one goal was to determine whether scientific research on human embryos should be permitted.

There were a number of tensions to resolve in formulating a public policy. The committee was aware that the general public held a variety of views on the moral status of human embryos, as did members of the committee. ${ }^{17}$ While the majority believed that the potential benefits meant very early embryos should be permitted to be used for research, some members dissented. However, the entire committee shared the belief that human embryos were special entities deserving of special protection under law. ${ }^{1}$ Finally, the committee was concerned to maintain public trust in researchers.

Warnock acknowledged that their proposal was a compromise. ${ }^{8}$ A majority of the committee believed research on embryos should be permitted under licence. To help allay public fears regarding 'unscrupulous scientists', ${ }^{1}$ a clear limit was needed. The 14-day rule met these requirements and could be justified based on an embryo's moral status, even if the committee's reasoning was controversial, as we later explain. The 14-day threshold was before the development of the 'primitive streak' at around 15 days after fertilisationthe point beyond which twinning was no longer thought to be possible. The committee's view was that prior to this point, the embryo could be regarded as a collection of cells, or a 'pre-embryo'. Only after this could the embryo be regarded as a definite individual and a potential person-an entity with rights, such as the right to life. ${ }^{1}$ The committee also noted that this limit was prior to the formation of the central nervous system at around 22 days, which would definitively rule out the possibility of the embryo experiencing pain.

${ }^{\mathrm{i}}$ This is not a claim that embryos around 22 days of age can experience pain. However, recently Stuart Derbyshire and John Bockmann argued that some kind of pain experience may be possible as early as 12 weeks, much earlier than previous estimates of 24 weeks. ${ }^{13}$ A limit prior to the start of the development of the central nervous system at around 22 days rules out any possibility of pain experience.
Given the significant influence of the Warnock Committee's deliberations, we believe that any proposal to extend the 14-day rule should examine the committee's reasoning and justify the extension on this basis. The two key considerations are maintaining public trust and providing a moral justification for researching embryos. The committee provided two reasons for morally justifying research on early embryos-the utilitarian argument, based on the perceived benefits of such research, and their argument based on the moral status of early embryos. We will examine how McCully's proposal deals with each of these.

\section{PUBLIC TRUST}

Warnock, in addressing the issue of public trust in researchers, warns that extending the limit will confirm the worries of those who argued that the initial 14-day rule would be the start of a 'slippery slope' to further extensions. ${ }^{8}$ She notes that the case of critics is made more plausible because the issue has only been raised since culturing beyond 14 days has become possible. ${ }^{8}$ This is likely to undermine public trust in such research, and for this reason, Warnock does not believe that the limit should be extended for now. ${ }^{8}$

McCully acknowledges that the 14-day rule has built considerable public trust but claims that worries about a slippery slope are not justified because the regulations are strict, making it illegal to slide down such a slope. ${ }^{4}$ She seems unaware that an extension of the 14-day rule is precisely the sort of slippery slope that opponents of the original act warned of.

\section{UTILITARIAN ARGUMENT}

McCully primarily focuses on the utilitarian argument to justify extending the limit to 28 days. She suggests researching this extended period will help to enable rates of miscarriage to be reduced, in vitro fertilization (IVF) outcomes to improve and the safety of new techniques such as gene editing to be tested. As researchers can access tissue from aborted fetuses that are more than 28 days old, currently the 14-28 day period is a 'black box' about which little is known.

Such benefits are possible, perhaps likely, outcomes of extending the limit. However, it only became possible in 2016 to culture embryos for up to 14 days, ${ }^{3}$ and so research into embryos of between 7 and 14 days is in its infancy; 
most discoveries to date have been within the first 7 days. $^{9}$ It seems premature to lobby for an extension to 28 days when the current limit has barely begun to be exploited; indeed, others arguing for an extension have suggested a far more conservative approach of 2 or 3 day increments and that only after extensive public consultation. ${ }^{6}$ It is also uncertain how accurately a postimplantation embryo culture would replicate the in utero environment, which may limit the applicability of research on embryos beyond 14 days.

\section{MORAL STATUS OF EMBRYOS}

McCully does not consider the Warnock Committee's argument for the 14-day rule based on the moral status of embryos-that only after the primitive streak appears is the embryo a distinct individual and a potential person. This seems a serious weakness in her proposal. Grant Castelyn ${ }^{5}$ explains that there are three supporting claims for this position: first, an empirical claim regarding twinning; second, that there is a relationship between the possibility of twinning and the embryo's identity; and third, that identity is sufficient for moral status.

Regarding the empirical claim, almost 40 years of embryology research has not significantly revised our understanding of individuation. The formation of the primitive streak still marks the start of gastrulation at around 14-16 days, when the embryo begins to differentiate into three separate layers, and beyond which twinning cannot usually occur. There are, however, two developments that may impact our understanding of when twinning occurs in opposing ways. First, research has shown that conjoined twins might arise-very rarely_after the primitive streak has formed, up to 21 days. ${ }^{10}$ Using the Warnock Committee's reasoning, this might support extending the limit by up to 7 days, still significantly less than McCully's proposed 28-day limit. However, the traditional model of postzygotic splitting for monozygotic twinning has been challenged. In 2013, Gonzalo Herranz proposed an alternative model of twinning, whereby monozygotic twinning occurs at the first division of the zygote. ${ }^{11}$ Definitive evidence for either model is lacking, ${ }^{11}$ but if Herranz's model prevails, this implies a dramatic reduction should be made in the 14-day limit.

An important question is the relationship between twinning and individual identity. In the vast majority of cases, embryos would never undergo twinning if allowed to develop, and so an individual is almost always present much earlier than 14 days, despite having the capacity to divide. Furthermore, even if twinning does occur, it might be that the prefission individual is the same individual as one of the postfission individuals. ${ }^{\text {ii }}$ Arguably, on this basis, the Warnock Committee should have set the limit much earlier.

Finally, let us consider the moral claimthat if a developing individual shares its identity with a future person, it has special moral status as a potential person. There is an intuitive appeal to the claim that 'I was once an embryo'- that each of us shares a numerical identity with an organism that existed prior to the onset of our psychological capacities. It has been employed by numerous ethicists to argue for the moral status of embryos. Although McCully does not directly engage this claim, she does briefly address the moral status of the embryo, citing Elsejin Kingma's view that an embryo's environment is relevant to its moral status. ${ }^{12}$ Kingma suggests that once a 'research embryo' is past the point that it can be successfully implanted (eg, a 14-day old embryo), it has no potential to become a human being. This implies it is morally unproblematic to extend the limit to 28 days.

However, this reasoning also implies that as medical technology develops, we could continue to extend this limit to just prior to the point of viability. This raises the possibility of laws eventually permitting experimenting on ex utero fetuses of up to 20 weeks or more, as they too would have no potential to become persons. More problematically, as Kingma herself notes, as soon as ectogenesis becomes an option, ${ }^{\mathrm{iii}}$ this argument becomes unsound-for embryos of any age, including those less than 14 days old.

\section{CONCLUSION}

The Warnock Committee proposed the 14-day limit for mainly pragmatic reasons-a clear limit was required for public trust, and it represented a compromise between the utilitarian argument, and

${ }^{i i}$ For instance, embryo A splits leading to embryo $\mathrm{B}$ and $\mathrm{C}$, one of which is identical to embryo A. Our thanks to an anonymous reviewer who suggested adding this point.

iii Interestingly, the Warnock Committee discussed the possibility of ectogenesis and its potential for observing normal and abnormal embryonic development in the future. the committee's view that human embryos deserve some legal protection. McCully does not seriously engage with the Warnock Committee's reasoning. Her use of Kingma's claim that an implanted embryo and a 'research embryo' have differing moral status is problematic. McCully's arguments could easily be used to justify extensions beyond 28 days, confirming slippery slope concerns among critics of the current limit and possibly undermining public trust. As Mary Warnock wrote recently, the 14-day rule should remain in place for now. ${ }^{8}$

\section{Twitter Daniel Rodger @philosowhal}

Contributors BPB wrote the majority of the first submission. DR was responsible for important suggestions. Both authors worked on editing the original submission to produce the revised submission.

Funding The authors have not declared a specific grant for this research from any funding agency in the public, commercial or not-for-profit sectors.

Competing interests None declared.

Patient consent for publication Not required.

Provenance and peer review Not commissioned; externally peer reviewed.

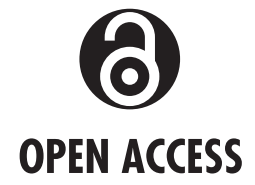

Open access This is an open access article distributed in accordance with the Creative Commons Attribution Non Commercial (CC BY-NC 4.0) license, which permits others to distribute, remix, adapt, build upon this work non-commercially, and license their derivative works on different terms, provided the original work is properly cited, appropriate credit is given, any changes made indicated, and the use is non-commercial. See: http:// creativecommons.org/licenses/by-nc/4.0/.

(C) Author(s) (or their employer(s)) 2021. Re-use permitted under CC BY-NC. No commercial re-use. See rights and permissions. Published by BMJ.

\section{(D) Check for updates}

To cite Blackshaw BP, Rodger D. J Med Ethics 2021:47:712-714.

Received 10 February 2021

Revised 21 April 2021

Accepted 25 April 2021

Published Online First 10 June 2021

$J$ Med Ethics 2021;47:712-714.

doi:10.1136/medethics-2021-107317

\section{ORCID iDs}

Bruce Philip Blackshaw http://orcid.org/0000-00029115-582X

Daniel Rodger http://orcid.org/0000-0002-2121-7167

\section{REFERENCES}

1 Warnock M. REPORT OF THE COMMITTEE OF INQUIRY INTO HUMAN FERTILISATION AND EMBRYOLOGY. London: Her Majesty's Stationery Office, 1984. http:// www.hfea.gov.uk/docs/Warnock_Report_of_the_ Committee_of_Inquiry_into_Human_Fertilisation_ and_Embryology_1984.pdf 


\section{Response}

2 Human fertilisation and embryology act, 2008. Available: https://www.legislation.gov.uk/ukpga/2008/ 22/contents [Accessed 6 Feb 2021].

3 Deglincerti A, Croft GF, Pietila LN, et al. Self-

Organization of the in vitro attached human embryo. Nature 2016;533(7602):251-4.

4 McCully S. The time has come to extend the 14-day limit. J Med Ethics 2021. doi:10.1136/medethics-2020-106406. [Epub ahead of print: 02 Feb 2021].

5 Castelyn G. Embryo experimentation: is there a case for moving beyond the '14-day rule'. Monash Bioeth $\operatorname{Rev} 2020 ; 38(2): 181-96$
6 Hyun I, Bredenoord AL, Briscoe J, et al. Human embryo research beyond the primitive streak. Science 2021;371(6533):998-1000.

7 Warnock M. Do human cells have rights? Bioethics 1987:1(1):1-14.

8 Warnock M. Should the 14-day limit on human embryo research be extended? BioNews, 2017. https://www. bionews.org.uk/page_95833

9 Williams K, Johnson MH. Adapting the 14-day rule for embryo research to encompass evolving technologies. Reprod Biomed Soc Online 2020;10:1-9.
10 Koch R, The Hegeler Institute. Conjoined twins and the biological account of personal identity. Monist 2006;89(3):351-70.

11 McNamara HC, Kane SC, Craig JM, et al. A review of the mechanisms and evidence for typical and atypical twinning. Am J Obstet Gynecol 2016:214(2):172-91.

12 Kingma E. Moral Status and the Properties of the Embryo. Human Embryo Culture. London: Nuffield Council on Bioethics, 2017: 73-7.

13 Derbyshire SW, Bockmann JC. Reconsidering fetal pain. J Med Ethics 2020;46(1):3-6. 